\title{
Morphology of sympathetic chain in Saguinus niger
}

\author{
MARINA P.E. PINTO ${ }^{1}$, ÉRIKA BRANCO ${ }^{1}$, EMERSON T. FIORETTO ${ }^{2}$, \\ LUIZA C. PEREIRA ${ }^{3}$ and ANA R. LIMA ${ }^{1}$ \\ ${ }^{1}$ Universidade Federal Rural da Amazônia (UFRA), Instituto de Saúde e Produção Animal - ISPA, \\ Faculdade de Medicina Veterinária, Avenida Perimetral, 2501, Belém, PA, Brasil \\ ${ }^{2}$ Universidade Federal de Sergipe (UFS), Cidade Universitária Professor José Aloísio de Campos, \\ Avenida Marechal Rondon, s/n, Jardim Rosa Elze, São Cristovão, Aracajú, SE, Brasil \\ ${ }^{3}$ Empresa Hydro LTDA, Mina de Bauxita - Paragominas, PA, Brasil
}

Manuscript received on March 20, 2012; accepted for publication on October 2, 2012

\begin{abstract}
Saguinus niger popularly known as Sauim, is a Brazilian North primate. Sympathetic chain investigation would support traumatic and/or cancer diagnosis which are little described in wild animals. The aim of this study was to describe the morphology and distribution of sympathetic chain in order to supply knowledge for neurocomparative research. Three female young animals that came death by natural causes were investigated. Animals were fixed in formaldehyde $10 \%$ and dissected along the sympathetic chain in neck, thorax and abdomen. Cranial cervical ganglion was located at the level of carotid bifurcation, related to carotid internal artery. In neck basis the vagosympathetic trunk divides into the sympathetic trunk and the parasympathetic vagal nerve. Sympathetic trunk ran in dorsal position and originated the stellate ganglia, formed by the fusion of caudal cervical and first thoracic ganglia. Vagal trunk laid ventrally to heart and formed the cardiac plexus. In abdomen, on the right side, were found the celiac ganglion and cranial mesenteric ganglion; in the left side these ganglia were fusioned into the celiac-mesenteric ganglion displaced closely to the celiac artery. In both sides, the caudal mesenteric ganglion was located near to the caudal mesenteric artery.
\end{abstract}

Key words: anatomy, primate, Saguinus niger, sympathetic chain.

\section{INTRODUCTION}

Saguinus niger is popularly known as Sauim, that inhabits from Guyana to Brazil, commonly encountered in the north of Amazonas River and east of Negro River towards Atlantic cost (Hershkovitz 1977). It is a Callitrichidae family genus considered to be one of the complex evolved neotropical primate. It is a black monkey with characteristically welldefined stain (brownish, reddish or yellowish), with

Correspondence to: Ana Rita de Lima

E-mail: vetlima@uol.com.br. hairless ears, weighting around 500g (Hershkovitz 1977). Its diet includes small vertebrates like tree frogs, geckos, small birds, flowers and fruits (Centro Nacional de Primatas 2010).

Peripheral autonomic nervous system, in rats and other mammals, connects the central nervous system to the viscera, and its arrangement consists of nerves and ganglia, which can be recognized either as swellings along the nervous trunk or confluence of various nerves. Ganglia are divided into paravertebral (cranial cervical, middle cervical, 
stellate or cervicothoracic, sympathetic thoracic and lumbars ganglia), prevertebral (celiac, cranial mesenteric or celiac mesenteric, caudal mesenteric, intermesenterics, aorticorenal, gonadal, renal and adrenal ganglia), paravisceral and intramural ganglia (Gabella 1995).

Cranial cervical ganglion is a very well developed structure, disposed ventrally to sternomastoideus muscle and covered by mandibular gland (Sheng et al. 1998). Stellate ganglion is considered a true nervous centre, consisting of a fusion of the caudal cervical and the first two or three thoracic ganglia, located at the level of the first two thoracic vertebras (Gabella 2004).

Celiac ganglia innervates stomach, intestine, liver and pancreas, and contributes to spleen innervations. It is considered to be essential for gastrointestinal motility control, aditionally, its innervation territory is important for abdominal surgery and clinics (Ribeiro et al. 2000a, b).

Cranial mesenteric ganglion is a centre of gastrointestinal reflexes integrations, while caudal mesenteric ganglion plays an important functional role in digestive tract (sympathetic innervations of colon and internal anal sphincter) and partially contributes to genital and urinary innervations (Gagliardo and Ribeiro 2005).

Besides the importance of the sympathetic nervous arrangement for diagnoses of traumatic and neoplasic processes, and the exhaustive studies in domestic and laboratory animals, only recently, comparative studies have been carried out, on the other hand, studies in wild species are still scarce. The present study aimed to investigate the morphology and distribution of sympathetic chain on S. niger in order to supply knowledge for neurocomparative researches.

\section{MATERIALS AND METHODS}

Sympathetic chain of three young female Saguinus niger were investigated. Animals have deceased from natural causes and were obtained at Paragominas, PA, Brazil, authorization numbers SEMA-PA 455/2009 and 522/2009. Specimens were fixed in a $10 \%$ formaldehyde solution. Sympathetic chain was dissected with the aid of a magnifying glass $(4.7 \mathrm{x})$ in the skull, neck, thorax and abdomen regions.

Ganglia length, thickness and width were surveyed in millimeters using a caliper rule. Illustrations of Veterinary Medicine Anatomical Nomina (Schaller 1999) were followed to name the structures.

\section{RESULTS}

Cranial cervical ganglion was located bilaterally and ventrally to the tympanic bulla, cranially to the common carotid artery and close to the internal carotid artery, presenting a fusiform shape and an average size of $4.0 \mathrm{~mm}$ length, $1.0 \mathrm{~mm}$ width and $0.5 \mathrm{~mm}$ thickness (Figure 1).

Stellate or cervicothoracic ganglion (Figure 2) was located at the proximal borders of subclavian ansa, on the dorsolateral surface of longissimus cervicis muscle, between first and second intercostals space. It was a discrete swelling in the sympathetic trunk, measuring around $2.5 \mathrm{~mm}$ length, $1.0 \mathrm{~mm}$ width and $0.5 \mathrm{~mm}$ thickness.

Celiac ganglion was identified in the right antimere (Figure 3), presenting elongate shape, around $2.0 \mathrm{~mm}$ length, $1.0 \mathrm{~mm}$ width and $0.5 \mathrm{~mm}$ thickness and laid along the caudal surface of celiac artery origin. Medially to the celiac ganglion we located the mesenteric cranial ganglion (Figure 3) at the origin of the cranial mesenteric artery origin, presenting $4.0 \mathrm{~mm}$ length, $2.0 \mathrm{~mm}$ width and $1.0 \mathrm{~mm}$ thickness.

On the left side we located a celiac mesenteric ganglion (Figure 4), emitting a fiber net involving the origin of celiac and cranial mesenteric artery, presenting $4.0 \mathrm{~mm}$ length, $3.0 \mathrm{~mm}$ width and $1.0 \mathrm{~mm}$ thickness.

Surrounding the caudal mesenteric artery, and laterally to the abdominal aorta, it was identified the caudal mesenteric ganglion in both antimeres 


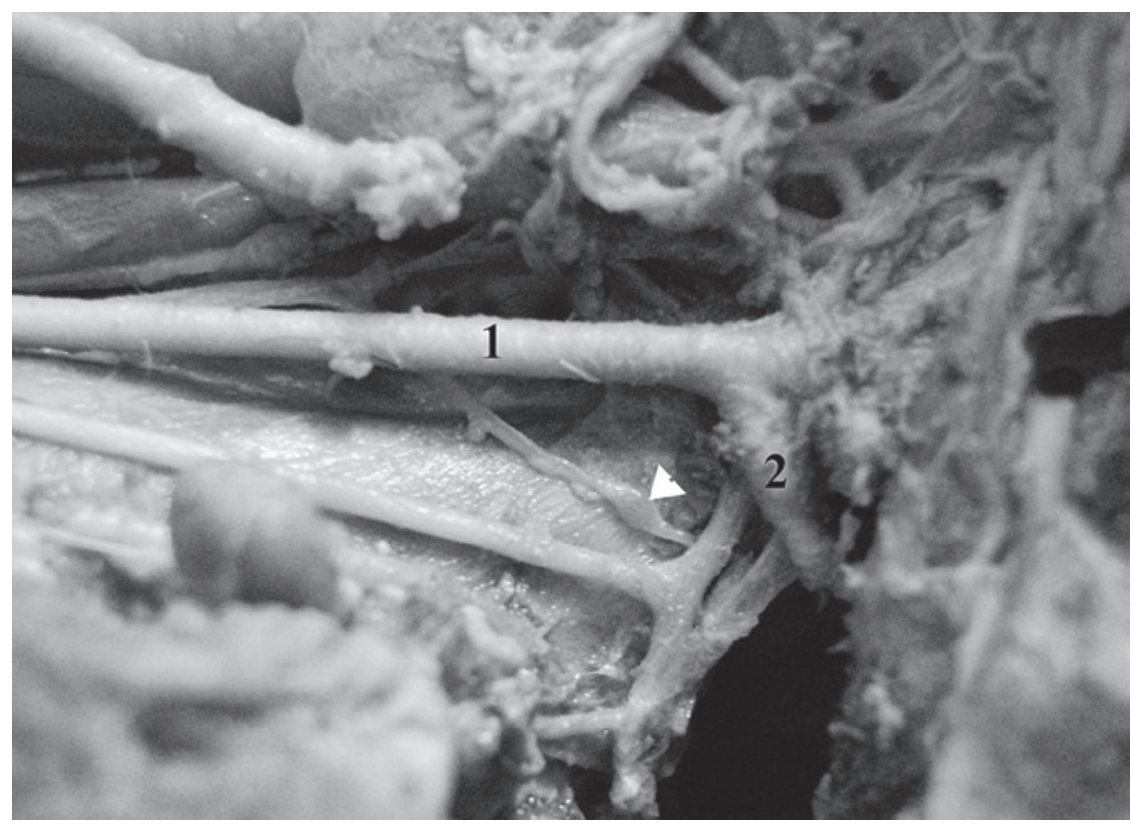

Fig 1 - Photomacrography of Saguinus niger left sympathetic trunk in lateral view demonstrating a cranial cervical ganglion (arrowhead), left common carotid artery (1) and left internal carotid artery (2).

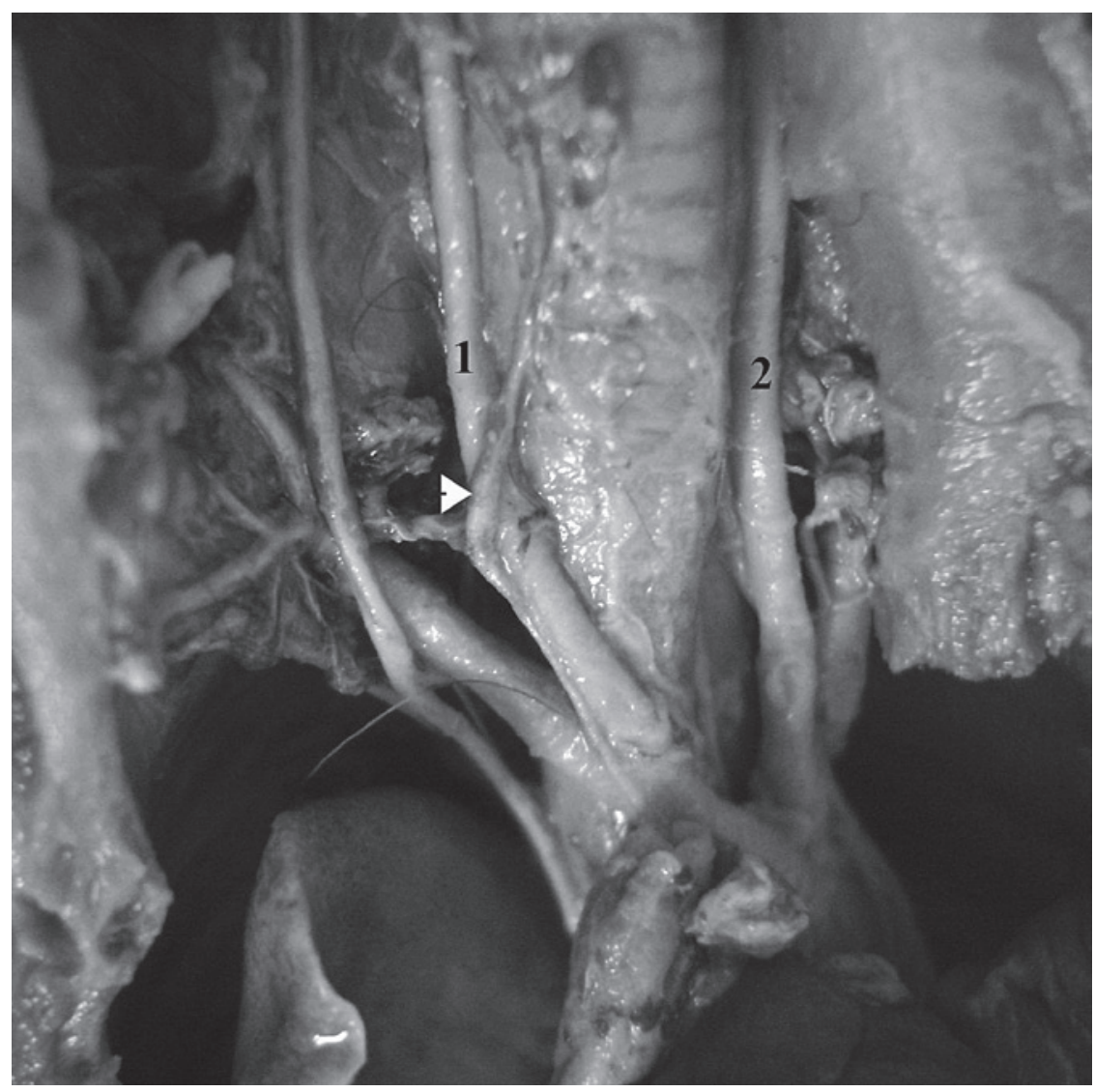

Fig 2 - Photomacrography of Saguinus niger sympathetic trunk in ventral view demonstrating a stellate ganglion (arrowhead), right (1) and left (2) common carotid arteries. 


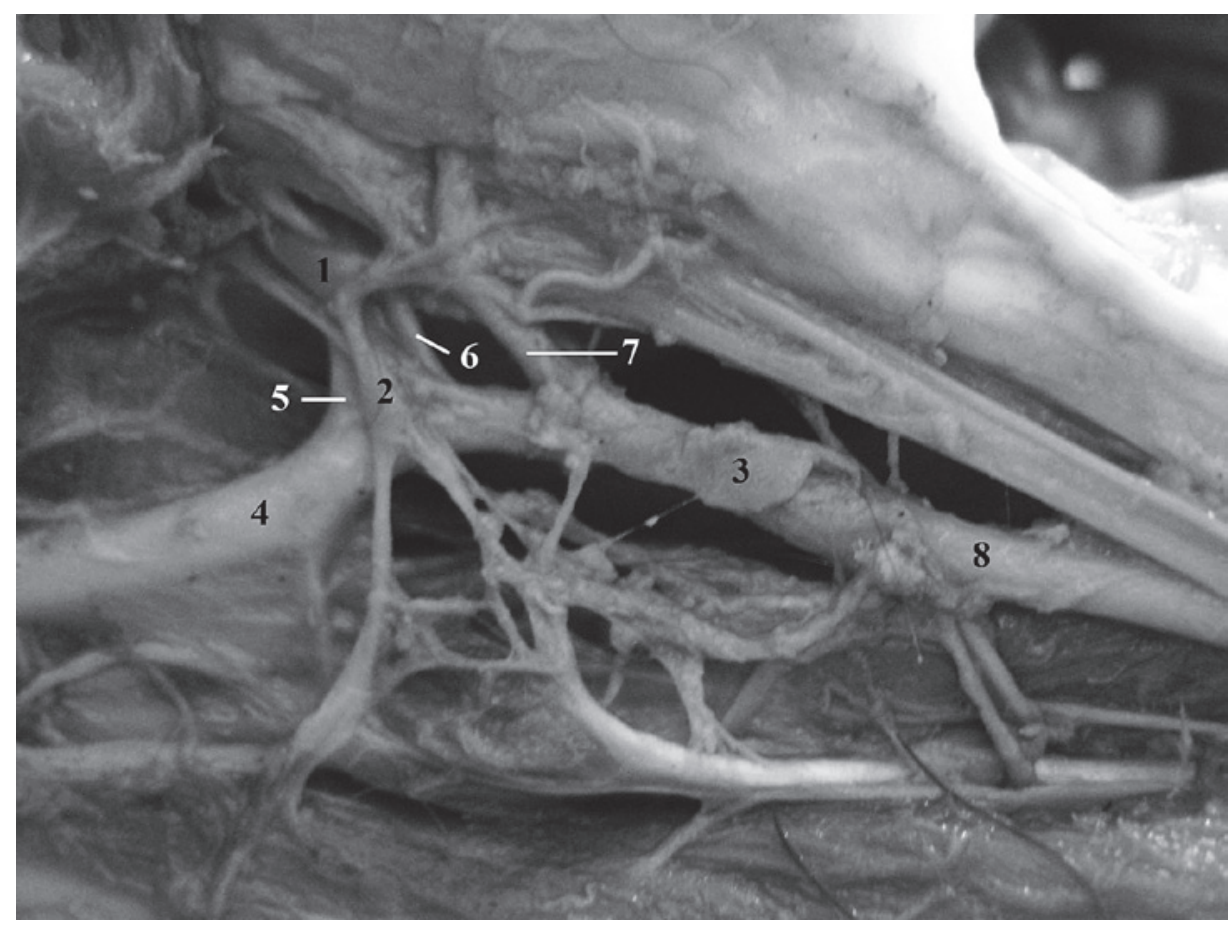

Fig 3 - Photomacrography of Saguinus niger right sympathetic trunk in abdomen in ventral view demonstrating the cranial mesenteric ganglion (1), celiac ganglion (2), caudal mesenteric ganglion (3), abdominal aorta $(\mathbf{4}, \mathbf{8})$, celiac artery (5), cranial mesenteric artery (6) and kidney artery (7).

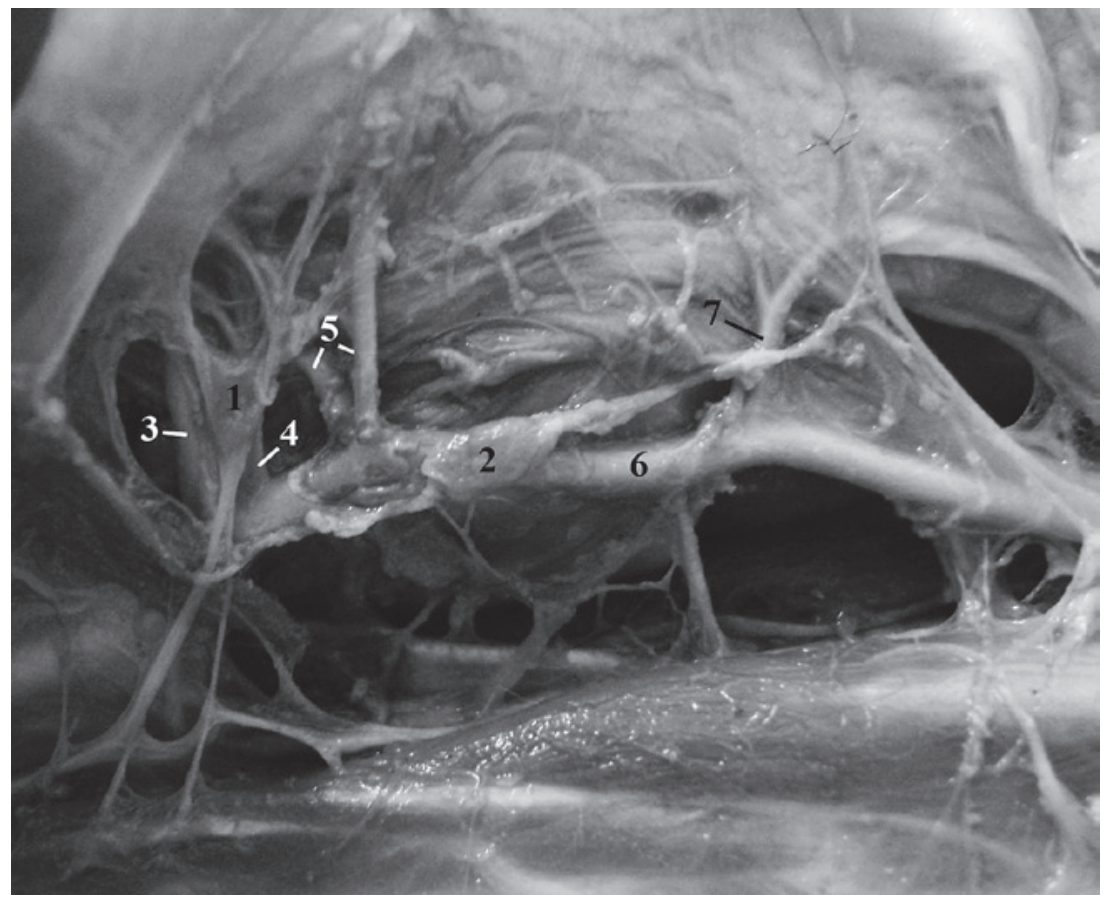

Fig 4 - Photomacrography of left side of a S. niger we can see the celiac mesenteric ganglion (1), round the origin of celiac (3) and mesenteric cranial (4) arteries and the mesenteric caudal ganglion (2) located caudally the origin of kidney arteries (5), laterally the abdominal aorta (6) and cranial to the mesenteric caudal artery (7). 
(Figure 3). Average measuring was $6.0 \mathrm{~mm}$ length, $2.0 \mathrm{~mm}$ width and $1.0 \mathrm{~mm}$ thickness in the right side and $6.0 \mathrm{~mm}$ length, $3.0 \mathrm{~mm}$ width and $1.5 \mathrm{~mm}$ thickness in the left side.

\section{DISCUSSION}

Cranial cervical ganglion was located ventrally to atlas, near to the common carotid artery, similarly to dogs (Fioretto et al. 2006). In human (Saylam et al. 2009), the location of superior cervical ganglion was considered to be the safest in the sympathetic chain, located caudally to the common internal carotid artery being necessary its retraction to exposure the ganglion at the level of the second cervical vertebra, measuring an average of $33 \mathrm{~mm}$ length and $8.1 \mathrm{~mm}$ of width. In Saguinus niger this ganglion demonstrated lesser size when compared to human, we believe that species size differences might be possibly related, however a relation between body size or body mass and ganglion size still need further evaluation.

In rats the stellate ganglion was located near to the second thoracic vertebra (Cavalcanti et al. 2006); in humans it is located either near to the seventh cervical vertebra or between the seventh cervical and first thoracic vertebra or only related to the first thoracic vertebra, its size was $11.3 \mathrm{~mm}$ length and $8.2 \mathrm{~mm}$ width (Saylam et al. 2009). In dogs, this ganglion is located in dorsolateral surface of the longissimus neck muscle at the level of first and second intercostals spaces and demonstrated an average $23 \mathrm{~mm}$ length, $4 \mathrm{~mm}$ width and $2 \mathrm{~mm}$ thickness (Getty 1986). The location of the stellate ganglion in Saguinus niger was more similar to the dog description.

When present, the celiac ganglion in Saguinus niger was considered similar to the domestic dog (Guidi et al. 2005), presenting an irregular shape and being located laterally and surrounding the celiac artery. The cranial mesenteric ganglion was located at the origin of cranial mesenteric artery in right side similarly to the domestic cat
(Felis catus domesticus) (Ribeiro et al. 2000a). A common variation in celiac and mesenteric ganglia construction is their fusion, forming the celiacmesenteric ganglion.

Celiac mesenteric ganglion in Saguinus niger was surrounding the celiac artery in the left antimere. In domestic cat this ganglion is a projection around the cranial mesenteric artery (Ribeiro et al. 2000a), while in buffalo, the celiac mesenteric ganglion demonstrated varied morphologic arrangements, being the most predominant a single ganglion divided in two portions (right and left) around celiac and cranial mesenteric arteries and the two portions joined at the level of caudal margin of the cranial mesenteric artery, presenting a semilunar shape (Ribeiro et al. 2000a). In dog, the celiac mesenteric plexus is arranged in a net around the origin of the celiac and cranial mesenteric arteries (Rocha and Massone 2006).

Caudal mesenteric ganglion was located laterally to aorta, around the origin of caudal mesenteric artery similarly to dog (Rocha and Massone 2006) in which the caudal mesenteric plexus originated from the caudal mesenteric artery and continued caudally to reach the pelvic plexus.

We can conclude that the sympathetic chain arrangement in Saguinus niger might be considered a bit similar to domestic animals, more specifically to domestic dog and cat. Cranial cervical, cervicothoracic, right celiac and caudal mesenteric ganglia were more similar positioned to dog descriptions, while the cranial mesenteric ganglion was more similar to cat descriptions in $S$. niger that also demonstrated the formation of fusioned celiacmesenteric ganglion.

\section{RESUMO}

O Saguinus niger popularmente conhecido como Sauim, é um primata do Norte do Brasil. A investigação da cadeia simpática pode dar suporte a diagnósticos traumáticos e/ou de câncer que são pouco descritos em animais selvagens. O objetivo deste estudo foi descrever 
a morfologia e a distribuição da cadeia simpática para suprir conhecimentos em pesquisas neurocomparativas. Foram investigadas três fêmeas jovens que vieram a óbito por causas naturais. Os animais foram fixados em formaldeído $10 \%$ e dissecados ao longo da cadeia simpática no pescoço, tórax e abdômen. O gânglio cervical cranial foi localizado ao nível da bifurcação carotídea, relacionado à artéria carótida interna. $\mathrm{Na}$ base do pescoço o tronco vago simpático se divide em tronco simpático e nervo vago parassimpático. O tronco simpático corre na posição dorsal e originou os gânglios estrelados, formados pela fusão dos gânglios cervicais caudais e do primeiro gânglio torácico. O tronco vagal passa ventralmente ao coração e forma o plexo cardíaco. No abdômen, no lado direito encontrouse o gânglio celíaco e o mesentérico cranial, no lado esquerdo estes gânglios estavam fusionados no gânglio celíaco-mesentérico disposto próximo à artéria celíaca. Em ambos os lados, o gânglio mesentérico caudal estava localizado próximo à artéria mesentérica caudal.

Palavras-chave: anatomia, primata, Saguinus niger, cadeia simpática.

\section{REFERENCES}

CAVAlCANTI RAO, Lima AR AND Ribeiro AACM. 2006. Quantitative effects of the physical activity on the extrinsic cardiac innervation in rats. In: International Conference on Stereology, Spatial Statistic and Stochastic Geometry, S4G, Praga. Proceedings S4G: 379-384.

CenP - Centro Nacional de Primatas. 2010. Guia de Espécies. Disponível em: <www.cenp.org.br>, Acessado em: 30 maio 2011.

Fioretto ET, Abreu RN, CAstro MFS, Guidi WL AND RIBEIRO AACM. 2006. Macro and microstructure of the superior cervical ganglion in dogs, cats and horses during maturation. Cells Tiss Organs 186: 129-140.
GABELLA G. 1995. The rat autonomic nervous system. London: Academic Press, 77 p.

Gabella G. 2004. Autonomic Nervous System. In: The Rat Nervous System. $3^{\text {rd }}$ ed., Elsevier, p. 77-99.

GAGLIARDO KM AND RIBEIRO AACM. 2005. Estudo morfométrico dos neurônios do gânglio mesentérico caudal de cães durante o desenvolvimento pós-natal (maturação e envelhecimento). Braz J Vet Res Anim Sci 43: 57-64.

GetTy R. 1986. Anatomia dos Animais Domésticos, $5^{\text {th }}$ ed., Rio de Janeiro: Guanabara Koogan, p. 1617-1634.

GUIDI WL, FIORETTO ET AND RIBEIRO AACM. 2006. Estudo morfométrico e estereológico do gânglio celíaco em cães sadios. Braz J Vet Res Anim Sci 43: 337-347.

HeRshKOVITZ P. 1977. Living New Wold Monkeys (Platyrrhini) with an introduction to Primates. Chicago: The University of Chicago Press 1: 707-708.

RIBEIRO AACM, MigLINO MA AND SOUZA RR. 2000b. Estudo anatômico dos gânglios celiaco, celiacomesentérico e mesentérico cranial e de suas conexões em fetos de búfalos sem raça definida (Bubalus bubalis, Linnaeus 1758). Braz J Vet Res Anim Sci 37: 267-272.

RibeIRo AACM, SouzA RR, BARBosA J AND FERNANDES FILHO A. 2000a. Estudo anatômico dos gânglios celíaco, celiacomesentérico e mesentérico cranial e de suas conexões no gato doméstico (Felix domestica, Linnaeus, 1758). Braz J Vet Res Anim Sci 37: 109-114.

RochA LMS AND MASSONE F. 2006. Estudo anatomoanestesiológico do segmento lombar (L1 a L6) em cães. Braz J Vet Res Anim Sci 43: 167-177.

SaYlam CY, OzGiray E, Orhan M, CaGli S AND Zileli M. 2009. Neuroanatomy of Cervical Sympathetic Trunk: A Cadaveric Study. In: Clinical Anatomy, p. 324-330.

SCHALLER O. 1999. Nomenclatura anatômica veterinária ilustrada. São Paulo: Manole, 614 p.

Sheng C, LING WL AND Ming XZ. 1998. The gross anatomy of the cranial cervical ganglion and its branches in the bactrian camel (Camelus Bactrianus). Vet Res Commun 22: $1-5$. 